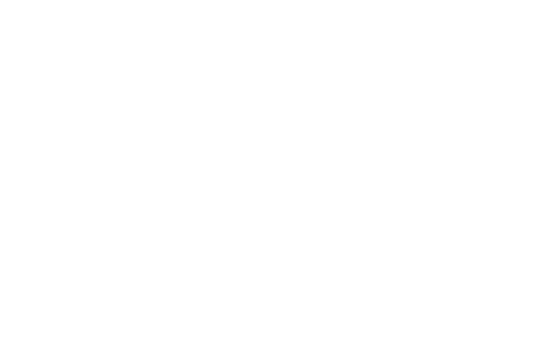

Annu. Rev. Sociol. 2010. 36:117-37

First published online as a Review in Advance on April 13, 2010

The Annual Review of Sociology is online at soc.annualreviews.org

This article's doi:

10.1146/annurev.soc.012809.102625

Copyright (C) 2010 by Annual Reviews. All rights reserved

0360-0572/10/0811-0117\$20.00

\section{From the Sociology of Intellectuals to the Sociology of Interventions}

\author{
Gil Eyal and Larissa Buchholz
}

Department of Sociology, Columbia University, New York, New York 10027; email: ge2027@gmail.com, lb2331@columbia.edu

\section{Key Words}

classical intellectual, intellectual fields and markets, expertise

\begin{abstract}
This review suggests that the sociology of intellectuals is being converted into a sociology of interventions, i.e., instead of focusing on a certain social type, it analyzes the movement by which knowledge and expertise are mobilized to inform a value-laden intervention in the public sphere. We first demonstrate that the classical sociology of intellectuals was centered on a problematic of allegiance that no longer seems productive. In addition, we show that by focusing on a particular social type it remained limited to only one mode of intervention into the public sphere. We then review two literatures that distance themselves from the classical problematic and that could be integrated under the common rubric of a sociology of interventions: The first literature analyzes intellectual fields and markets. It moves away from the sociology of intellectuals by multiplying the relevant actors and depersonalizing the term "intellectual" so that it no longer stands for a social type but for the capacity to make a public intervention, a capacity to which many different actors lay claim. The second literature analyzes the public deployment of expertise. It multiplies not simply the actors laying claim to the mantle of the intellectual, but the formats and modes of intervention itself, i.e., the different ways in which knowledge and expertise can be inserted into the public sphere.
\end{abstract}




\section{INTRODUCTION}

There are several reasons why writing a review of the sociology of intellectuals is not a straightforward task. The most immediate one is that a great deal of the most recent literature on intellectuals seems to announce their decline and disappearance. This is particularly true for the specifically American debate about "public intellectuals." Beginning in 1987 with the publication of Jacoby's The Last Intellectuals, the neologism "public intellectuals" has sparked a resurgence of debate about intellectuals, yet most of it has been confined to the question of whether they are a dying breed or not (Jacoby 1987, Kellner 1997, Donatich 2001, Posner 2001, Fuller 2004, Townsley 2006, Drezner 2008, Fleck et al. 2009). This discussion resonates with some of the founding texts of the sociology of intellectuals, which were typically written in a genre characterized by Posner (2001) as a jeremiad, a rant (mixture of lament and accusation) about decline and betrayal (Benda 1927 [1928], Molnar 1961, Jacoby 1987). For a reviewer, the problem is thereby not so much whether such diagnoses are correct or not, but how to characterize a literature of which one main principle of multiplication has been the claim that its object is dissolving. Is the very project of the sociology of intellectuals becoming more and more anachronistic and a review, therefore, redundant?

To be sure, if one looks beyond the contemporary American scene, one may take heart that the sociology of intellectuals is alive and well, not only regarding work on classical historical cases, such as Russia and France, but also when it comes to the contemporary non-Western world (Kurzman \& Owens 2002). But this seems cold comfort, for it could be taken to imply that when these countries "catch up," they too will shed the central role of intellectuals and that the sociology of intellectuals is thus essentially a backward-looking twentieth-century affair. The task we set for this review, therefore, is not merely descriptive but also reconstructive: to extract from the recent literature the parameters and research directions of what may be reasonably termed a twenty-first-century sociology of intellectuals.

This reconstructive approach may begin with the observation that the diagnostic dispute about the death or resurrection of the public intellectual ultimately boils down to a matter of definition, to boundary work (Gieryn 1999): The "Jeremiahs" define the object of the sociology of intellectuals restrictively, its prototype being the man of letters who intervenes in the public sphere in the name of universal truth and morality, the classical embodiment provided by Zola's F'accuse. Consequently, they bemoan its decline. The "boosters" define it expansively to include the whole gamut of educated types. Consequently, they dilute the object beyond recognition. Both, in fact, have been going at it for quite a while. Almost from the very moment the term "intellectuals" was invented (during the Dreyfus affair) and the sociology of intellectuals began to take shape, it spread outward into various sociologies of the intelligentsia (Mannheim 1936), organic intellectuals (Gramsci 1932 [1995]), men of knowledge or ideas (Znaniecki 1940 [1968], Coser 1965 [1970]), producers of culture (Lipset \& Dobson 1972), or the "new class" (Makhaiski 1899 [1979], Djilas 1957, BruceBriggs 1979, Gouldner 1979, Konrad \& Szelényi 1979). This outward movement was met with a countermovement, asserting that "these are not real intellectuals" and providing its own diagnosis of decline and betrayal (Benda 1927 [1928], Molnar 1961, Jacoby 1987). Then the cycle would begin again.

The cyclical nature of this dispute is no doubt due to the highly reflexive nature of the very project of the sociology of intellectuals. As Bauman (1987, pp. 2, 8) puts it, any definition of intellectuals is a self-definition and therefore "it makes little sense... to ask the question 'who are the intellectuals?' and expect in reply a set of objective measurements." This is one reason why the reconstructive task we set for this review is not a willful choice, but is necessitated by the type of literature with which we are grappling. Any definition of the scope of this review would rely on boundary work 
between "intellectual" and "nonintellectual" and would thereby be reconstructing the very universe in which the review itself is positioned. A review of the sociology of intellectuals is thus meta-reflexive and has to attend to its own positioning within a history of definitions and counterdefinitions (see also Townsley 2006).

This lengthy preamble is meant to justify the analytical strategy underlying this review. A sociology of intellectuals for the twenty-first century cannot adopt a restrictive and obscurantist definition of its scope, but neither can it dilute its object beyond recognition. Diagnostically, the work of reconstruction begins by rejecting, with Fleck et al. (2009, p. 1), the narrative of decline in favor of transformation: "Over the years, new groups of intellectuals have entered the public arena while older ones have disappeared.... [T] he twenty-first-century intellectual is very different in his or her aspirations and functioning role when compared to the type that more than a hundred years ago was emerging." Regarding the United States, for instance, Jacobs \& Townsley (2010) demonstrate that its "space of opinion"-i.e., the sort of publicly oriented commentary in which intellectuals specialize - has in fact grown in size and become more heterogeneous in recent years, rather than declined. Such changes imply that a sociology of intellectuals for the twenty-first century must be different from the classical sociology of intellectuals. As its object changes, so should its substantive questions and conceptual tools. Yet the work of reconstruction we envision eschews expanding and diluting the object beyond recognition in favor of a careful work of conversion, seeking to identify certain constants that were foundational for the twentieth-century sociology of intellectuals as a research project and showing how their specific content is being modified in the contemporary context of emerging novel questions and research strategies.

Our inspiration for this strategy comes from Foucault's (2000) distinction between the "universal" and "specific" intellectual. Whereas the universal intellectual corresponded to the classic image of the engaged man of letters, the specific intellectual was rather an expert whose work was more narrow and local, yet served as a basis for intervening in the public sphere. Foucault thus pointed to the emergence of a new type of intellectual, not immediately recognizable as such by classical definitions. What made these experts "specific intellectuals"? For Foucault, it was not any substantive quality of the actors involved, but a particular kind of movement they embodied: "[T]he intellectual is simply the person who uses his knowledge, his competence and his relation to truth in the field of political struggles" (p. 128). Although this movement remains a constant object of the sociology of intellectuals, its specific componentsWho is moving? On the basis of what relation to truth? What type of political agency is constituted by this movement? - were transformed, for example by the greater centrality of scientific discourse today or by changes in the public sphere. Yet note that this does not simply imply an expansive definition of intellectuals because not every expert thereby automatically becomes an object for the sociology of intellectuals, but only one who participates in this movement. Conversion in this sense means that one carefully identifies the enduring elementthe movement by which knowledge acquires value as public intervention-and translates it into a new set of conditions and corresponding research strategies.

The strategy of conversion has been elaborated further by Bourdieu (1992 [1996]), who noted that it is the high degree of specialization characteristic of modern science that made it inappropriate to speak of the specific intellectual in the singular and that the type of movement characteristic of the classical intellectual was more effectively undergone by a "collective intellectual," a group of experts working in unison. Bourdieu also emphasized that conversion is necessary not only in time, between epochs, but also across space, between different countries and institutional contexts.

What we take from Foucault and Bourdieu is the idea that the classical sociology of intellectuals needs to be reconstructed, converted into a twenty-first-century sociology of 
interventions. The main difference between the sociology of intellectuals and the sociology of interventions is that the former takes as its unit of analysis a particular social type and is preoccupied with showing how the social characteristics of this type explain where its allegiances lie, whereas the latter takes as its unit of analysis the movement of intervention itself and is therefore interested in how forms of expertise can acquire value as public interventions. Yet the story we tell in this review is also different from Foucault's or Bourdieu's. Conversion from the sociology of intellectuals to the sociology of interventions does not yield a binary opposition in which specific or collective intellectuals replace classical ones, but a more dispersed and fragmented picture: Multiple discourses, multiple sociologies, multiple objects of analysis now occupy the field of debate and research that originally belonged to the classical sociology of intellectuals.

These considerations explain the structure of the review. The first section is an intentionally short and stylized review of the main common characteristics of the classical sociology of intellectuals, from its inception until roughly 1980. The choice of 1980 is not meant as an exact periodization, but as a way to construct a baseline against which to highlight the novel developments of the past 30 years. It was selected as a watershed year because it is bordered by two significant dates. First, 1979 marked a high tide in the "new class" literature, i.e., in the expansive trend of the sociology of intellectuals. It witnessed the publication of several major books (Bruce-Briggs 1979, Gouldner 1979, Konrad \& Szelényi 1979, Walker 1979, Debray 1979 [1981]), some of which argued that intellectuals were poised to become a dominant class. Yet, at the other end of the 1980s one finds almost the exact inverse moment, namely Jacoby's (1987) invention of the redundant neologism of "public intellectual," a narrowing to the restrictive classical meaning of the term, and a narrative of decline and lament. No doubt the end of the Cold War has contributed to this reversal. One needs only to recall the brief moment of glory enjoyed by East European dissidents and their almost immediate fall from grace as postcommunist countries settled into the gray reality of neoliberal capitalism (Eyal 2000, 2003; Tucker 2000) to appreciate how this moment may have translated into a renewed focus on the classical meaning of intellectuals. We would like to parlay the sense of reversal and fragmentation that lies between these two points in time into the aforementioned distinction between the classical sociology of intellectuals and a twenty-first-century sociology of interventions.

Thus, the subsequent section and the one that follows it review works that distance themselves from the classical sociology of intellectuals in two different directions. We propose that these two could perhaps be integrated under the common rubric of a sociology of interventions. The first literature analyzes intellectual fields and markets. It moves away from the sociology of intellectuals by multiplying the relevant actors and depersonalizing the term "intellectual" so that it no longer stands for a social type but for the capacity to make a public intervention, a capacity to which many different actors lay claim. Works in this direction situate all the different claims within a common relational sphere such as a field or a market and analyze the competition between the various actors over the symbolic prestige contained in the very title of intellectual, as well as the relations of supply and demand governing intellectual interventions.

In the third and final section, we review works in the sociology of expertise that seem to represent a different and perhaps complementary move away from the classical sociology of intellectuals. They multiply not simply the actors laying claim to the mantle of the intellectual, but also the formats and modes of intervention itself. Here the focus is directed at the different ways in which knowledge and expertise can be inserted into the public sphere and with what sorts of effects. Instead of analyzing the preconditions for the jump from one domain to the other, works in this direction describe how fuzzy zones of contact and overlap are created, wherein forms of expertise and 
discourse develop that are common to both politics and science.

\section{THE CLASSICAL SOCIOLOGY OF INTELLECTUALS, 1900-1980}

In this section, we trace the main contours of the classical sociology of intellectuals, describing in broad outline the questions, definitions, and theoretical orientations that characterize it as a relatively unified configuration. We do not provide a detailed historical discussion of the development of the sociology of intellectuals, however, because this has been done elsewhere (Martin \& Szelényi 1988, Kurzman \& Owens 2002). Instead, our focus is directed at selected key contributions to the sociology of intellectuals from the turn of the century to the 1980s in order to reconstruct an ideal typical baseline against which to highlight and evaluate transformations and new trends in the past 30 years. ${ }^{1}$

One key component of this baseline was an empirical puzzle- - "under what conditions do intellectuals become radicalized in their political behavior?"- -shared by classical sociologists of intellectuals as a common "point of diffraction" (Foucault 1972) from which a game of moves and countermoves unfolded. Many classical sociologists of intellectuals have sought to explain intellectuals' role as radical critics of the social order and leaders of revolutionary movements (Makhaiski 1899 [1979]; Brinton 1938 [1965]; Schumpeter 1942, pp. 145-55; Dahrendorf 1953 [1969]; Lasch 1965; Lipset \& Dobson 1972; Bruce-Briggs 1979). This query was countered by other sociologists of intellectuals who have sought to explain why modern intellectuals were no longer radical critics, but profoundly absorbed into the machineries of established powers (Mills 1944 [1963],

\footnotetext{
${ }^{1}$ We made no systematic attempt to sample representative readings because this would be an inappropriate approach to a highly interpretative literature consisting of moves and countermoves. Instead, we compiled a fairly comprehensive list of works in the sociology of intellectuals from this period based on preexisting reviews and then chose the works that, in our judgment, were enduring and significant for the development of the classical problematic.
}

Chomsky 1969, Debray 1979 [1981]), perhaps even standing at their helm (Konrad \& Szelényi 1979). Finally, the sequence of moves was completed by analyses that sought to demonstrate the diversity and contingency of intellectuals' political roles (Michels 1932, Shils 1958 [1972], Coser 1965 [1970], Eisenstadt 1972, Brym 1980), with perhaps the final statement in that period delivered by Brint (1985; cf. also 1994).

Other key empirical puzzles that characterized the classical sociology of intellectuals and that no longer seem to hold such fascination for contemporary sociologists were (a) the partisan role of nationalist or party intellectuals, signifying for some a betrayal of their mission as defenders of universal values (Benda 1927 [1928]), yet for others the very means through which intellectuals' commitment to "the life of the mind" worked its way to a universal synthesis (Mannheim 1932 [1993], 1936, 1956); and (b) the question of the class position of intellectuals "between labor and capital," which for some signified that they were a "new class" mobilized to pursue its own collective interests (Bakunin 1870 [1950], Nomad 1937, Djilas 1957, Bruce-Briggs 1979, Gouldner 1979, Konrad \& Szelényi 1979) yet for others that they merely played a supporting role on behalf of more "fundamental" classes (Gramsci 1929-1935 [1971], Walker 1979).

All three puzzles can be boiled down to a single one. The classical problematic of the sociology of intellectuals was dominated by the question of allegiance. Who are the intellectuals and to whom or to what do they owe allegiance? For example, the debate about the class position of intellectuals ultimately was about whether they owed allegiance to their own class (as suggested by new class theorists) or to another class (as suggested by the concept of organic intellectuals). Similarly, accusations of partisanship and betrayal à la Benda; diagnoses of decline due to the rise of corporations and bureaucracies (Coser 1965 [1970], Mills 1944 [1963]); investigations into the radical potential of intellectuals all were part of a debate about whether intellectuals owed allegiance to truth (Mills 1944 [1963]), universal values (Benda 1927 [1928]), 
the sacred (Shils 1958 [1972]), the life of the mind (Mannheim 1932 [1993], 1936, 1956), ideas (Coser 1965 [1970]), or material interests (Chomsky 1969). The political and ethical problematic of allegiance was prior to the empirical puzzles of class positions or role expectations. It was the foundation upon which they were formulated. The sociology of intellectuals was meant to deliver an answer to this problem, but, given that any definition of intellectuals is a self-definition (Bauman 1987), this answer could be anything but straightforward. To whom do we owe allegiance, the classical theorists were asking, and nothing was more symptomatic than Gouldner's (1979) wager that the intellectuals were "our best card in history." Gouldner, an otherwise careful thinker, never clarified who were the "we" of this assertion and how could "we" be meaningfully distinguished from "they," namely the intellectuals who were supposedly our best hope.

Why was the question of allegiance so central? One has to return to the original formulation of the term "intellectuals" during the Dreyfus affair to recall that it emerged as a mobilizing device in the course of political struggle. It was a rallying call designed to bring into being the very category it was naming and a strategy of making claims on behalf of reason relevant in political struggles (Bauman 1987). So from its very inception it was inscribed with a duality or ambiguity of allegiance, simultaneously a claim to rise above sectarian interests and to mobilize in a field of struggles on behalf of one segment to which it attempted to give shape and purpose.

The most characteristic symptom of this duality or ambiguity of allegiance was the tendency of the literature to swing between romantic and satirical forms of emploting the history of intellectuals (White 1973). Like all tribal societies, intellectuals were in need of a myth of origin or meta-history to explain to themselves who they were and where their allegiances lay. The classical sociology of intellectuals, therefore, was preoccupied with pinpointing the precise historical conditions under which intellectuals in the classical sense appear and thrive.
Yet from its very inception it was torn between romantic meta-narratives of self-discovery and triumph through struggle, and satirical meta-narratives of complicity, betrayal, and decline: Whereas one set of analyses sought to specify the historical trends that enabled the emergence of intellectuals as a distinct social group or stratum in modern societies (Mannheim 1936; Znaniecki 1940 [1968]; Schumpeter 1942, pp. 145-55; Shils 1958 [1972]; Coser 1965 [1970]; Gouldner 1979; Konrad \& Szelényi 1979), a second strand was focused on diagnosing and explaining their decline (Benda 1927 [1928], Gramsci 1929-1935 [1971], Mills 1944 [1963], Coser 1965 [1970], Chomsky 1969).

Classical definitions of the intellectuals also reflected this duality of allegiance. Despite variations, they broadly shared four core features that constituted what can be termed the prototype of the classical intellectual: ${ }^{2}$ First, typically definitions were of intellectualsqua-social substance-a social type, a group, or a class-by opposition to nonintellectualslaypeople, technical experts, and politicians. Second, intellectuals were identified as those whose work involved the use and manipulation of abstract knowledge or symbols, in contrast to those whose tasks depended more on immediate sensory experience and directed toward immediate practical goals (Benda 1927 [1928]; Michels 1932; Mannheim 1936; Shils 1958 [1972]; Coser 1965 [1970]; Lipset \& Dobson 1972; Bell 1973 [1976], 1979; Gouldner 1979; Konrad \& Szelényi 1979). Third and related, intellectuals were characterized by their commitment to universal values as opposed to particular interests or power (e.g., Benda 1927 [1928], Shils 1958 [1972], Mills 1944 [1963], Coser 1965 [1970]). Finally and

\footnotetext{
${ }^{2}$ A prototype is a "best example" of a certain category that is grouped together by family resemblance rather than a strict definition of necessary and sufficient conditions. Thus, "robin" is a prototypical bird, and the engaged man of letters was a prototypical intellectual of the earlier twentieth century. Other members of the category are arranged in order of proximity or distance from the prototype (Rosch 1978, pp. 27-48; Hacking 1995, pp. 23-24).
} 
most specifically, intellectuals intervened in political life on the basis of these two defining features, that is, abstract knowledge and the commitment to universal values. In essence, the classical prototype of the intellectual referred to a specific formatting of political agency: the capacity to use abstract knowledge for a criticaluniversalistic mode of public engagement and intervention. At the same time, however, definitions of intellectuals also tended to include a secondary clause that relaxed the opposition and permitted the extension of the category away from the prototype either on a temporal axis, as in Gramsci's (1929-1935 [1971]) distinction between traditional and organic intellectuals; or along a continuum of occupational differentiation, as in Lipset's \& Dobson's (1972, p. 137) distinction between jobs that "involve the creation, distribution and application of culture"; or by means of a totalizing concept such as the "new class" (Bruce-Briggs 1979, Gouldner 1979); or dialectically, when the capacity for transcendence emerged out of the immanent play of particular interests (Mannheim 1936, Bourdieu 1975, Konrad \& Szelényi 1979). In this way, they injected a duality into the very definition of the intellectual.

The conceptual tools deployed by the classical sociology of intellectuals were borrowed in the hope that they could give an answer to this question of allegiance. They were "allegiance captures" in the sense that they were meant to represent a stable cause or basis for the enduring allegiance of intellectuals. The two usual suspects were interests and norms (or role expectations). Borrowed from Marxism, class analysis reformulated the question of allegiance as about interests (Gramsci 1929-1935 [1971], Bell 1979, Bruce-Briggs 1979, Gouldner 1979, Konrad \& Szelényi 1979), whereas the analysis of traditions, social roles, and values, influenced by functionalism and symbolic interactionism, reformulated it as about normative expectations and commitments (Znaniecki 1940 [1968], Shils 1958 [1972], Coser 1965 [1970]). This meant that despite their differences, all the main currents within the classical sociology of intellectuals were trying to deduce the worldviews or political attitudes of intellectuals directly from larger societal trends or position in social structure. The more interesting and complex thinkers-Michels, Mannheim, Gouldner, Konrad, and Szelenyi-however, recognized the need for mediating concepts and were thereby led to introduce a certain looseness into their respective "allegiance captures." The reflexive endeavor of the sociology of intellectuals gradually forced the classical literature toward a more probabilistic, relational, and eventual mode of explanation characteristic, we argue, of a twenty-first-century sociology of intellectuals. This transformation was most evident in Bourdieu's (1985a,b) replacing of the concept of class with field and in Foucault's (1972) replacing of truth/ideas with discourse.

We construe the task of our review, therefore, as partly diagnostic and partly reconstructive. To fathom the dimensions and potentialities of a twenty-first-century sociology of intellectuals, one would need to perform a structural conversion of the classical sociology of intellectuals. The problematic of allegiance referred to a particular formatting of political agency, the claim to intervene in the public sphere in the name of abstract knowledge and universal values. The enduring element here, what needs to be converted, is better expressed not in substantive terms, but in dynamic ones. It is the movement, the maneuver by which a historically specific truth-producing practice becomes an effective tool of intervention in the public sphere. This question, we suggest, is at the heart of a twenty-first-century sociology of intellectuals.

\section{THE SOCIOLOGY OF INTELLECTUAL FIELDS AND MARKETS}

The growing body of work on intellectual fields and markets involves a significant modification and reorientation away from the classical problematic. It expands the relevant domain of research beyond the predominant focus on the allegiances and political behavior of intellectuals and, due to its relational methodology, 
reconstructs the very object of investigation as intellectual fields or markets.

In fact, despite internal differences, the sociology of intellectual fields and markets typically rejects the attempt to define intellectuals in an a priori fashion as a social group with a set of objective attributes. Substantivist definitions are rejected not only because the attributes associated with intellectuals may vary systematically across different groups of cultural producers (Rahkonen \& Roos 1993, Camic \& Gross 2001), historical periods (Ringer 1990, p. 282), or countries (Bourdieu 1990, p. 145, Bourdieu 1992 [1996], pp. 343-44), but more importantly because they are also themselves stakes in struggles among specialized producers of knowledge over the claim to truly embody the mantle of the intellectual (Bourdieu 1990, p. 143). Thus, rather than predefining intellectuals through a set of substantive qualities, studies that draw upon the field framework approach their object by reconstructing the space within which intellectual attributions and related values are created and contested. It could be a "space of opinion" constructed around the practice of providing commentary (Jacobs \& Townsley 2010) or more generally a space of modes of public engagements (Sapiro 2009a). Either way, these studies depersonalize the object of analysis, redirecting the focus from particular social types or groups to the study of intellectual spaces, their sociocultural properties, and the multiple positions and claims that they encompass.

\section{Relative Autonomy}

Research building on the intellectual fields/markets approach has evolved around three main strands: The first analyzes the making, structure, and transformation of particular intellectual fields, with the most attention paid thus far to the French academic field (e.g., Bourdieu 1984 [1988], Ringer 1992, Kauppi 1996). This line of research is perhaps most in continuity with the classical sociology of intellectuals. The problematic of allegiance is overcome yet preserved in the pride of place that this line of research accords to the question of autonomy. Bourdieu explains that he developed the concept of field precisely to break with the illusion of intellectuals as disinterested and free-floating-i.e., owing allegiance only to ideas. Yet he also sought to go beyond the symmetrical claim that intellectuals have betrayed their calling and owe allegiance to material interests, either their own or those of others (Bourdieu 1980 [1993], p. 43; Bourdieu 1989, p. 20). Field analysis rejects such either-or attributions of allegiance, drawing attention to how fields as relatively autonomous arenas of struggle give rise to fieldspecific, yet internally (differing) affiliations, alliances, and oppositions. It thereby demonstrates that even those intellectual activities that would seem the most autonomous and detached are preconditioned by the structure of the field in which they are embedded. Universalitya key aspiration associated with classical autonomous intellectual position-takingsdepends on precise-and rare-structural conditions involving initial accumulation of resources, high barriers to entry, and a dynamic of competition for recognition among peers (Bourdieu 1989, p. 17; cf. also Bourdieu 1975; Bourdieu 1992 [1996], pp. 340-48).

By the same token, however, field analysis in this version preserves the problematic of allegiance at the level of an overall assessment of the degree of autonomy of the field. Ringer (1992), for example, compares the French and German debates on academic reform at the fin de siècle (1890-1920) to explain the emergence, in France, of an autonomous "academic culture" that favored intellectual specialization and a modernist research ethos, while in Germany by contrast the same struggles ended with the continuation of the more holistic and less autonomous notion of Bildung. The field concept thus serves Ringer to trace and contrast the divergent formations of intellectual allegiances and attitudes in a relational perspective (Ringer 1992, pp. 13-14).

Bourdieu's (1984 [1988]) Homo Academicus, although limited to France and more structural in data and approach than Ringer, also uses the 
field concept to characterize the overall degree of autonomy of the intellectual endeavor. $\mathrm{He}$ shows that the French university field is characterized by an internal structure that corresponds largely to the structure of privilege and domination in the larger social space. Although indices of heteronomy, of political or temporal power, increase in weight as one moves from the faculties of science and arts to law and medicine, indices of autonomy, that is, of specific scientific authority and intellectual recognition, decrease (Bourdieu 1984 [1988], p. 48).

Kauppi's (1996) analysis of the transformation of the French intellectual field in the period from 1960 to 1980 similarly seeks to diagnose a global transformation in the structure and autonomy of the intellectual field. The main argument is that the original bipolar structure of the field—structured by the opposition between the figure of the men of letters at the literary pole and the scholar at the university polehas been transformed into a tripolar structure by the growing relevance of media publicity as a resource for intellectual recognition, and the overall effect is a decrease in autonomy. By comparison, Jacobs \& Townsley (2010) provide a more nuanced assessment of the transformation in modes, authors, and sites that provide media commentary. They show that although indices of heteronomy increase over time in TV talk shows, they do not do so in the op-ed sections of major U.S. newspapers, thus providing a more complex assessment of the effect of media publicity on the intellectual field, which they conceptualize as polarization rather than an overall decrease of autonomy.

\section{Genesis and Circulation of Models of Intellectuals}

The second strand within the intellectual field/market approach pulls further away from the classical problematic of allegiance as it eschews global characterizations. These studies typically use the concept of the intellectual field to explain the emergence, success, or failure of certain models or figures of intellectuals and related modes of public intervention. Three works in this line set out to provide genetic accounts of aspects of the universalistic-critical prototype of the intellectual, the central focus of the classical tradition. Charle's (1990) study reconstructs the conditions under which intellectuals emerged as a social category in France. He argues that this neologism constituted a response to a crisis of the literary and artistic professions at the end of the nineteenth century (Charle 1990, p. 64), a crisis caused by mismatch between the growing numbers of candidate members and the dearth of professional artistic outlets (Charle 1990, pp. 38-63). This situation led to heightened competition, the multiplication of declassed aspirants, and ultimately a crisis of established representations of the intellectual métier itself (e.g., "l'homme de lettres," "l'artiste," "le savant"). Against this background, the concept "intellectuals," Charle (1990, p. 55) suggests, permitted the formulation of a new professional ideal of intellectual work and collective identity for social protest.

The second work, by Sapiro (2003), aims to explain the emergence of a specific mode of politicization among writers-which she calls "prophesying." Like Charle, Sapiro combines Bourdieu's field analysis with theoretical elements from the sociology of professions. Yet her argument centers not so much on heightened rivalry within artistic professions, but on the increasing competition that writers faced with other, newly emerging professional groups of experts. In this situation, she holds, prophesying became a preferred mode of political intervention because it allowed writers to compensate for their lack of specific expertise and redefine "their social function in face of the growing influence of new professional experts and their values of scientific accuracy and technical competence" (Sapiro 2003, p. 640).

The third work, by Boschetti (1985 [1988]), deploys field analysis to explain the rise to prominence of perhaps the prototypical classical intellectual, Sartre. She shows how Sartre's rise was predicated on the recognition granted by established authorities of consecration, and how his claim to embody the "total intellectual" unified and reconciled two previously 
antagonistic poles of the French intellectual field-professors and artistic creators.

More recent studies have extended this line of research beyond the French case and the figure of the classical intellectual. Medvetz (2009, 2010), for instance, documents the institutionalization of an interstitial field of think tanks in the United States, situated between the fields of politics, academia, the economy, and the media. This hybrid space, he argues, has made possible a new figure of public intellectual whose authority is not so much based on a particular type of intellectual or scientific expertise, "nor on the command of economic capital, political power or media access, but rather on the capacity to mediate an encounter among these forms of authority" (Medvetz 2010). Ultimately, he holds, this new hybrid intellectual field marginalizes earlier more autonomous modes of intellectual intervention (Medvetz 2010).

Another recent trend in this strand of field research has been to expand the analytical approach from national to transnational perspectives (cf. Sapiro 2009c). Charle's (2009) comparison of models of intellectual engagement in different European countries at the end of the nineteenth century, for instance, goes beyond contrasting the internal structure of intellectual fields to take into account also phenomena of transnational intellectual exchange and transfer. As he argues, variations in traditions of intellectual commitment-e.g., the French Dreyfusard intellectual, the British public moralist, or the Russian intelligentsia-not only reflect developments within national fields, but also are shaped by the circulation of models of intellectual engagement across national borders, albeit reinterpreted and modified. Boschetti (2009) analyzes the European intellectual space from 1945 to 1960 to argue that the unequal influence of certain figures or models of intellectuals across countries was affected by hierarchies not just within, but also between intellectual fields. One cannot make sense of Sartre's far-reaching success beyond France, for instance, without considering the dominant position of Paris in the European intellectual space and even across the Atlantic. Her argument thereby resonates with pioneering work on transnational cultural spaces in the context of literary translation (Casanova 1999 [2004], Heilbron \& Sapiro 2007), which has highlighted the importance of analyzing transnational asymmetries between national fields and the way in which they structure the dynamics of cultural exchanges between national fields. This is an exciting new direction for field analysis that promises to move beyond the still prevailing methodological nationalism in comparative research on intellectuals. It could be developed further through combining it with the novel method of "entangled history" (bistoire croisée) (cf. Werner \& Zimmermann 2003, pp. 7-36; Sapiro 2009b).

\section{Modes of Intervention}

The third and last strand within the intellectual field/market literature distances itself the furthest from the classical problematic by documenting and explaining extensive variation in modes of public intellectual engagement both within and between national cases. In a sense, it moves away from a focus on the allegiance of intellectuals or the autonomy of the intellectual field and toward an analysis of modes of intervention themselves.

Sapiro (2003, 2009a) develops a useful analysis and typology of public intellectual interventions. Drawing on Bourdieu's field concept, she seeks to relate variations in the mode of public intellectual engagement to different positions that intellectuals occupy. In an earlier contribution (Sapiro 2003, pp. 64147), she suggested, for instance, that forms of political engagement (e.g., genres of protest, such as manifestos, petitions, patronage, or the lampoon) vary according to the positions that writers occupy in the French literary field, encompassing, ideal typically, the avant-garde, aesthetes, notabilities, and journalists. A more recent work (Sapiro 2009a) extends this approach to the wider French intellectual field as a space in which various cultural producers compete for the imposition of the legitimate vision of the social world in the public arena. As she 
suggests, the different modes of public intervention thereby practiced by different cultural producers-e.g., in regard to their chosen genre (ranging from prophesy or expertise), discursive forms (e.g., the pamphlet or the diagnosis), or modalities (individual or collective) - differ systematically according to their position in the intellectual field, which is structured along three axes (Sapiro 2009a, pp. 10-15): first, the overall amount of symbolic capital, which correlates with the likelihood that the mode of intervention will be individualistic rather than collective; second, the degree of independence from external political demand, which affects the likelihood that an intervention will take an autonomous discursive form; third, the degree of specialization insofar as the more specialized actors are more likely to intervene in the context of professional, organized bodies rather than as individuals and to justify intervention by reference to specialized expert knowledge rather than to universal values. Based on these three structuring factors, Sapiro (2009a, pp. 14-31) constructs a model of the French intellectual field that distinguishes ideal typically between seven modes of intellectual intervention: the critical, universalistic intellectual; the custodian of the moral order; intellectual contentious groups and avant-gardes; intellectuals from institutions or political organizations; the expert; the specific intellectual; and the collective intellectual. This model multiplies the likely intellectual actors and their typical modes of intervention and thereby moves the furthest from the classical sociology of intellectuals.

A related though different typology of modes of political engagement by intellectuals has been developed by Eyal (2000, 2003). Drawing on Bourdieu's field approach to explain the dynamics of elite formation in late communist Czechoslovakia, he identifies four discursive strategies-dissidence, internal exile, reform communism, and co-optation-each involving a different conception of the role of intellectuals and a different mode of intervening in public affairs. These modes or strategies are then probabilistically related to different social positions in the late communist field of power and serve to explain likely political affinities and alliances among intellectual fractions within it (Eyal 2000, p. 54; Eyal 2003, pp. 11-13, 26-34, 59-92).

An unlikely further example of this strand is Posner's (2001) study of the market for public intellectual work in the United States. Although Posner is no Bourdieusian, his market analysis of public intellectual work bears affinities to the field approach. Public intellectual work, says Posner, constitutes a relatively coherent arena of activity that is governed by the laws of demand and supply (Posner 2001, p. 2). Yet it also differs significantly from other cultural markets because of the nature of the specific commodity purveyed by public intellectuals. This focus on the commodity rather than on the actors means that Posner no longer aims to elucidate the allegiances of intellectuals, but to analyze the dynamics of how intellectual knowledge or opinion is made to circulate in the public sphere. He argues that "market failure" is responsible for the fact that the public sphere is flooded with public intellectual goods of dubious and poor quality: The barriers to entry are too low (it does not take much to write an op-ed piece, for example), and there is hardly any quality control mechanism that would encourage market exit because comments or predictions by public intellectuals are rarely scrutinized for their accuracy or effectiveness (e.g., there are no real consequences to writing a silly opinion or false prediction) (Posner 2001, p. 72). Additionally, his analysis is similar to Sapiro's in that he identifies multiple genres of public intellectual engagement: self-popularizing, own-field policy proposing, real-time commentary, prophetic commentary, jeremiad, general social criticism, specific social criticism, social reform, politically inflected literary criticism, political satire, and expert testimony (Posner 2001, pp. 2, 36-40).

To summarize, the literature on intellectual fields and markets offers several modifications of the classical sociology of intellectuals: $(a)$ a shift in the construction of the object from particular types of intellectuals toward the spaces in which intellectual practices are embedded 
and interrelated; (b) the introduction of fields as intermediate structured spaces between macrostructural factors and modes of intellectual public intervention; and $(c)$ an analytical approach that accounts for multiple modes of public intervention and that shifts attention from the allegiances of actors to the mode of their intervention. Nevertheless, existing research on intellectual fields and markets still suffers from too narrow a focus on the French case and a dearth of comparative frames that would assist in generalizing the results of research on specific national fields. The recent interest in transnational phenomena could contribute to overcoming these limitations and to articulating comparative and transnational methodologies in fruitful, novel ways.

\section{SOCIOLOGIES OF EXPERTISE}

In this final section, we review works from mainly three research traditions-social studies of science and technology (SSST), governmentality, and the international relations literature on "epistemic communities"-in order to reconstruct the broad outlines of a sociology that takes as its unit of analysis the movement of public intervention itself. We begin with the caveat that such a project is not the explicit goal of any of the works surveyed, but it involves a certain reconstructive reading on our part. Yet we think there is good basis for it. Indeed, what has been called the "third wave" of SSST has now moved from an earlier concern with the social construction of scientific knowledge to the problem of expertise, i.e., how and what kind of knowledge could serve as a legitimate basis for intervention in public affairs (Collins \& Evans 2002). The focus on intervention itself rather than on a particular social type is evident in the choice of terms to designate the new direction taken by SSST: "studies of expertise and experience" (Collins \& Evans 2002), "making things public" (Latour \& Weibel 2005), or "public science" (Wynne 2005). Governmentality studies, for their part, analyze how the exercise of power in contemporary societies is infused with knowledge about the nature of what is gov- erned and what it means to govern. In this sense, they are the mirror image of studies of expertise. They begin not with knowledge seeking to enter the public sphere, but with public authorities seeking to equip themselves with a truthproducing practice. In recent years, links between SSST and the governmentality literature have been forged on the basis of their common interest in the role that knowledge plays in public affairs (Rose et al. 2006). Finally, the literature on epistemic communities essentially deals with how ideas and their carriers penetrate and influence international relations (Haas 1992, pp. 3-4, 26-27; Keck \& Sikkink 1998, p. 213).

Here, we highlight three common tendencies of these literatures that we think together compose an analytical grid for empirical research focused on interventions themselves.

\section{Distributed Agency}

Compared with the field literature surveyed in the previous section, the response to the question of who intervenes is not necessarily to multiply the actors and array them all within a space of competition, but to highlight multiplicity within the intervening actor itself, which is conceptualized as an agency constituted, constructed, and assembled in and through the very movement of intervention.

Epistemic community is "a network of professionals with recognized expertise and competence in a particular domain and an authoritative claim to policy-relevant knowledge within that domain or issue area" (Haas 1992, p. 3; Adler \& Haas 1992; Keck \& Sikkink 1998; King 2005). It is distinct, however, from disciplines and professions because it is relatively small and because its members share principled beliefs and values (Haas 1992, pp. 3, 18; Keck \& Sikkink 1998, p. 30). Substantively, this literature can be seen as a successor to the classical sociology of intellectuals because, like classical intellectuals, epistemic communities are defined by the combination of truth claims with a public moral stance and because the concept is meant to show how the movement from ideas to public intervention may be accomplished, even 
in such a hostile environment as interstate relations and Realpolitik. ${ }^{3}$

At the same time, however, epistemic communities are conceived not simply as groups of intellectuals or experts, but as networks. The emphasis is not on the sociological character of their members, but on their formatting as vehicles of effective intervention. This formatting involves a cross-disciplinary combination of forms of expertise as well as transnational network ties, both crucial for influencing public discourse and diffusing policy innovations globally (Adler \& Haas 1992, pp. 378-79, 390; Keck \& Sikkink 1998, pp. 6-9). Epistemic communities "are channels through which new ideas circulate from societies to governments as well as from country to country" (Keck \& Sikkink 1998, p. 27; see also King 2005). The focus of the concept, therefore, is not on characterizing a social type and asking where its allegiances lie, but on the conditions for effective intervention, for bringing expertise to bear on public affairs. Among these conditions, Adler \& Haas (1992) identify the reach of the network, its capacity to build transgovernmental and transnational coalitions, and its positioning as an ideas broker within these coalitions.

One of the most prominent tendencies in SSST in the last decade has been the attention paid to the phenomenon of "lay expertise" (Epstein 1995, 1996; Wynne 1996; Rabeharisoa \& Callon 2004; Collins \& Evans 2002, 2007; Silverman \& Brosco 2007; Eyal et al. 2010), namely the capacity of ordinary people, often

\footnotetext{
${ }^{3}$ The connection between intellectuals and Realpolitik is intimate and constitutive. Intellectuals have formed themselves as a group, during the Dreyfus affair, in opposition to the secrecy justified by Raison d'état, and by emphasizing cosmopolitan ideals against narrow state interests. "Speaking truth to power" has been a distinctive intellectual genre (Tucker 2000), yet neoconservative intellectuals have created their identity partly by championing Realpolitik against what they perceived as naive moralism of liberal intellectuals, and nationalist intellectuals thrive on the critique of "rootless" cosmopolitan intellectuals. It is significant, therefore, that the concept of epistemic communities was launched as a meta-commentary on this dispute and that Latour's (2005) foray into the public intellectual role was titled "From $R e$ alpolitik to Dingpolitik" and includes a sophisticated critique of Realpolitik.
}

organized in networks, to develop specific expertise in matters of concern to them and to press recognition of their point of view. This attention to lay expertise served to highlight the heterogeneity of the actors intervening in the public sphere and led SSST to explicitly pose the question of expertise, i.e., how far could be extended the right to participate in public decision making about technical matters without degenerating into a free-for-all (Collins \& Evans 2002, 2007). Once SSST began to ask what is expertise, however, rather than who are the experts, the possibility opened up for analyzing expertise as a distributed property, a property not of individuals or even of groups (Collins 1990, Dreyfus \& Dreyfus 2005), but of a whole network that needs to be put in motion for a statement to hold up, circulate, and produce effects. The origins of this approach can be found in Foucault's (1963 [1994], 1972) dissection of the "clinical gaze" as a complex enunciative modality composed not only of individuals and their training, but also of spatial and institutional arrangements, instrumentation, concepts, and even the authority delegated to doctors by the state.

These initial insights were further developed by Actor-Network Theory, especially in the literature on performativity, which argues that economic models perform, i.e., shape or even bring into being, markets (Latour 1987, 1999; Callon 1998, 2005; MacKenzie et al. 2007). This literature, too, is a successor to the classical sociology of intellectuals because in the past three decades economists have probably been the most influential and visible policy experts and intellectuals-in-politics (Montecinos 1988, Markoff \& Montecinos 1993, Eyal 2000, Montecinos \& Markoff 2001, Babb \& Fourcade 2002, Dezalay \& Garth 2002, Fourcade 2006) and more importantly because it deals with a key question for the sociology of intellectuals: How is knowledge inserted into the public sphere and with what effects (Fourcade-Gourinchas 2003)? If it is hard to recognize the affinity between performativity and the sociology of intellectuals, this is because performativity is an effect not of economists 
per se, but of a whole network of material devices, accounting tools, institutional arrangements, and economic formulas. In short, the agency of intervention is analyzed as an assemblage wherein the expert, the economist, is only one component (Callon 1998, 2007). Or put differently, performativity begins from the assumption that we all are-even if we are experts, let alone old-style amateurish intellectuals-disabled or more precisely incompetent. "Imagine a society consisting primarily of disabled persons," writes Callon (2005, p. 313), by which he means lacking specific technical competence; "how can it be transformed into a democracy, when markets are constantly spawning new controversies, the technical content of which is becoming increasingly esoteric?" Effective intervention in public controversies is only possible by assembling the necessary material and cognitive and social equipment, as so many prostheses, into a coherent form of agency. Hence Callon's tongue-in-cheek slogan- "disabled persons of all countries unite"-is meant to refocus the attention of sociologists away from the persons intervening and onto the organizational, material, and cognitive equipment that enables effective intervention. His examples include consumer unions, patient groups, and issue groups formed by those affected by environmental pollution. All began from relative weakness and acquired the capacity to intervene in the public sphere by collecting data, setting up experiments, redirecting the flow of information, and striking coalitions across the science-state-society and lay-expert divides.

A similar move toward decentering the intervening agent is evident in studies of governmentality (Foucault 1977-1978 [2007], Burchell et al. 1991, Rose 1992, Barry et al. 1996, Valverde 1998, Rose et al. 2006). Governmentality is an approach to the study of political power as involving multiple and competing arts of governing human conduct. Arts of government are ensembles of discourses, practices, and institutions, i.e., of both knowledge and power. Like performativity, therefore, governmentality deals with the problem of how knowledge is inserted into the public sphere, although perhaps from the other side. Performativity asks how theoretical statements can produce real effects, whereas governmentality asks how the act of ruling is infused with a political rationality. For our purposes here, the crucial point is that these political rationalities or arts of government involve not only a specific conception of the human material upon which government acts-whether it is a flock, a territory, legal subjects, or a population-but also of the subject of this activity, who and what kind of an actor is the governor, and of what does the activity of governing consist. The subject of government, therefore, does not preexist the activity of governing, but is constituted in and through this activity. Similarly, when intellectuals are discussed within the governmentality paradigm, as in Osborne's (2004) analysis of "mediators," care is taken to emphasize that the discussion is not of intellectual types, but of "epistemic forms" or "ethical technologies" upon which individuals draw to legitimate or make sense of particular kinds of intellectual conduct. Like arts of government, such forms involve a specific conception of the "substance," the raw material of intellectual work, as well as a specific form of "stylization" of this work, the ethos the intellectual will embody. In the case that Osborne (2004, p. 434) discusses, a university research center that seeks to influence policy by "brokering alignments of interest and concern among differing constituencies," the substance is facilitating "vehicular ideas," and stylization involves an aesthetic attitude toward ideas, a will to create something new in the realm of ideas. The focus, however, is on the analysis of epistemic forms that constitute their own agentic modalities.

\section{Truth Effects}

These three literatures signal a transition from the sociology of intellectuals to the sociology of interventions not only because they decenter the intervening agent, but also because they draw attention to the multiplicity of truth-producing practices and modes of 
intervention. Arguably, the classical concept of the intellectual, while ostensibly describing social types, was in fact describing one genre of interventions characteristic of "public intellectuals," namely the manifesto, the signed petition, the polemical op-ed piece (and now the blog), the gesture of "revelation," prophesying, "speaking truth to power," as well as "transformative ideas" (Bell 1960, Gouldner 1975-1976, Bauman 1987, Haas 1992). Bauman (1987) characterized this genre as "legislation," speaking in the name of universal truth and morality. The literature on epistemic communities seems to reject precisely this mode of intervention when it declares that "epistemic communities are neither philosophers, nor kings, nor philosopherkings" (Adler \& Haas 1992, p. 371). Instead, scholars in this research tradition emphasize the capacity of epistemic communities to link opposing sides and-in conformity with Bauman's (1987) construal of postmodern intellectuals as "interpreters"- translate their interests in a way that facilitates communication and compromises among different involved parties (Adler \& Haas 1992, p. 382). This is true also for the transnational networks of activists that most closely approximate a twenty-first-century version of critical intellectuals (Keck \& Sikkink 1998).

Recent developments in SSST generalize this move away from the mode of intervention identified with classical intellectuals and support it with a historical argument about a changing public sphere. The edited volume and exhibition titled Making Things Public (Latour \& Weibel 2005) demonstrate how to make use of the rich conceptual resources provided by SSST in order to document multiple modes of intervention in public affairs, "the frail conduits through which truths and proofs are allowed to enter the sphere of politics" (Latour 2005 , p. 19). They begin from the observation, central to the Lippmann-Dewey debate of the interwar years (Lippmann 1922, 1927; Dewey 1927; Marres 2005), that modern-day politics are thoroughly suffused with complex technical issues about which the public is ignorant.
This does not mean, however, that democracy founded on public opinion is an empty shell masking the rule of experts. The experts as well are fairly ignorant about newly emerging "matters of concern" that typically involve complex and unforeseen technical details. It means, however, that democratic politics no longer takes place in a singular and rarefied public sphere where ideas are debated, but in multiple settings, wherever matters of concern bring forth and assemble new types of publics who educate themselves and equip themselves with the prosthetic devices necessary to address technical matters (Callon 2005). A good example is what Rabeharisoa \& Callon (2004) call "coproduction." They study the mode of action and intervention innovated by the French Muscular Dystrophy Association and show that, because both experts and patients were relatively ignorant about this complex and understudied condition, public decision making in this case was neither authoritative medical prescription nor technical response to politically articulated interests, but had to be infused with a hybrid discourse, partly technical and partly strategic, that facilitated cooperation and mutual learning.

Some conduits, however, are not as frail as others, nor as collaborative. The performativity literature, for its part, argues that economics "performs, shapes and formats the economy, rather than observing how it functions" (Callon 1998). This means also that economists intervene in the public sphere not-or not primarily-by opining about the economy, but when they invent new methods and devices that frame transactions in a way that permits new types of calculation and brings new markets into being. Put differently, performativity means that the Paul Krugmans of the world are not the privileged subject of a sociology of interventions, but rather technical innovators such as Fisher Black and Myron Scholes are (MacKenzie \& Milo 2003, MacKenzie et al. 2007).

Similarly, scholars of governmentality have demonstrated how various types of expertisepsychological expertise (Rose 1992), actuarial 
risk knowledge (Castel 1991, Feeley \& Simon 1992, O'Malley 1996), even the low-tech expertise of Alcoholics Anonymous (Valverde 1998)_are grafted onto programs for governing workplaces, markets, crime, or alcohol consumption, and how they redefine thereby the objects of governmental intervention and public debate (Miller \& Rose 1990). Osborne's (2004) typology of epistemic forms articulates a distinction between four modes of intervention or, in his language, strategies of intellectual work: (a) Legislation is a mode of intervention designed to bring about social and political order by imposing universal abstractions to which conduct must conform; $(b)$ interpretation seeks to bring about understanding and mutual recognition amid the clash of cultures and values, by reading all cultural forms as texts and translating between different speech communities; $(c)$ expertise limits itself to providing factual and true information at the disposal of government; and $(d)$ mediation intervenes in the public sphere by means of vehicular ideas to bring about innovation and a constantly mobile, creative culture.

\section{Interstitial Domains}

Finally, the transition from the sociology of intellectuals to the sociology of interventions entails not only decentering the agency of intervention and multiplying the modes of intervention, but also reenvisioning the space along which the movement of intervention proceeds. Intervention is analyzed not as a daring plunge from one (tranquil, academic) world into another (agonistic, political), but as taking place in an interstitial domain of expertise, where the boundaries between these worlds are blurry. In the classical sociology of intellectuals, as well as in field analysis, there is a chasm between the sphere of ideas ["a world apart" (Bourdieu 1990)] and the messy world of political action, over which the public intellectual must leap at his or her peril. Hence, there is the classical depiction of "intellectuals-in-politics" as "babes in the woods," naive and lost among powers they do not quite understand and that soon devour them, or as thoughtlessly pronouncing on matters for which they lack expertise (Joll 1960, Hamburger 1965, Jennings \& Kemp-Welch 1997, Lila 2001, Posner 2001).

The great merit of governmentality studies is to completely reject this spatial image. Arts of government are at one and the same time styles of thought and political practices. In analyzing arts of government, one does not have politics on one side and knowledge and intellectual life on the other, but on the contrary, one is describing an interstitial domain where the boundaries between the two are blurry, a domain composed of movements (Mitchell 1991, Rose et al. 2006). Osborne's (2004) "mediator" seems to embody this theoretical tendency: "[T]he mediator is simply the one who gets things moving." To mediate is not to stand in between as a passive intermediary, but to get things going from one place to another by means of "vehicular ideas."

Similarly, Callon (2007) has revised his initial characterization of performativity as the effect not of theoretical armchair economics, but of "economics in the wild," i.e., of the total set of actors-whether central bank economists, market professionals, statisticians, engineers, or credit unions-involved in collective analysis and configuration of markets. Once again, the daring plunge of cool theoretical economists into the hot whirlpool of markets becomes the exception that proves the rule, namely that for the most part intervention is only possible on the ground provided by a preexisting interstitial domain. In fact, it is the same domain in both cases, namely the domain of government, for what is to perform a market but to frame calculations so as to render transactions governable?

To complete this whirlwind tour through these complex theoretical traditions, let us note that epistemic communities are conceptualized not only as transdisciplinary and transnational networks, but crucially as transgovernmental networks, i.e., "invisible colleges" that stretch across different arms of government, over into various informal circles outside bureaucratic channels, and outward to include also nongovernmental actors, policy circles, think tanks, and academic institutes (Haas 1992, pp. 31-33). 
The capacity of epistemic communities to influence public debate and decision making is a function precisely of their hybrid and interstitial position (see also Eyal 2002).

\section{CONCLUSION}

We have argued that the classical problematic of the sociology of intellectuals no longer constitutes a fruitful basis for a research program, and we have surveyed two other literatures that, while addressing some of the central concerns of the sociology of intellectuals, are better characterized as converging on a new project of a sociology of interventions. Whether such convergence is ultimately feasible is an open question. Two of the common tendencies identified in the previous section-distributed agency and multiplicity of modes of intervention-do not seem to constitute an obstacle to such convergence. It is the third tendency to locate intervention in interstitial domains that poses the greatest challenge because it seems to go directly against the image of a bounded and relatively autonomous field. Reconciling field analysis with the notion of interstitial domains of expertise would be a major step toward a twenty-first-century sociology of interventions.

\section{DISCLOSURE STATEMENT}

The authors are not aware of any affiliations, memberships, funding, or financial holdings that might be perceived as affecting the objectivity of this review.

\section{LITERATURE CITED}

Adler E, Haas PM. 1992. Conclusion: epistemic communities, world order and the creation of a reflective research program. Int. Organ. 46:367-90

Babb S, Fourcade M. 2002. The rebirth of the liberal creed: paths to neoliberalism in four countries. Am. F. Sociol. 108:533-79

Bakunin M. 1870 [1950]. The state and Marxism. In Marxism, Freedom, and the State, ed. transl. KJ Kenafick, pp. 26-39. London: Freedom

Barry A, Osborne T, Rose N. 1996. Foucault and Political Reason. London: UCL Press

Bauman Z. 1987. Legislators and Interpreters: On Modernity, Post-Modernity and Intellectuals. Cambridge, UK: Polity

Bell D. 1960. The End of Ideology. Glencoe, IL: Free Press

Bell D. 1973 [1976]. The Coming of Post-Industrial Society: A Venture in Social Forecasting. New York: Basic Books

Bell D. 1979. The new class: a muddled concept. See Bruce-Briggs 1979, pp. 169-90

Benda J. 1927 [1928]. The Treason of the Intellectuals. New York: William Morrow

Boschetti A. 1985 [1988]. The Intellectual Enterprise: Sartre and Les Temps Moderns. Evanston, IL: Northwest. Univ. Press

Boschetti A. 2009. La recomposition de l'espace intellectuel européen après 1945. See Sapiro 2009c, pp. 147-82

Bourdieu P. 1975. The specificity of the scientific field and the social conditions of the progress of reason. Soc. Sci. Inf. 14:19-47

Bourdieu P. 1980 [1993]. How can "free-floating intellectuals" be set free? In Sociology in Question, transl. R. Nice, pp. 41-48. London: Sage

Bourdieu P. 1984 [1988]. Homo Academicus. Stanford, CA: Stanford Univ. Press

Bourdieu P. 1985a. The genesis of the concepts of habitus and field. Sociocriticism 2:11-24

Bourdieu P. 1985b. The social space and the genesis of groups. Theory Soc. 14:723-44

Bourdieu P. 1989. An interview with Pierre Bourdieu: for a socio-analysis of intellectuals on Homo Academicus. Berkeley 7. Sociol. 34:1-29

Bourdieu P. 1990. The intellectual field: a world apart. In In Other Words: Essays Towards a Reflexive Sociology, transl. M Adamson, pp. 140-49. Stanford, CA: Stanford Univ. Press 
Bourdieu P. 1992 [1996]. The Rules of Art. Genesis and Structure of the Literary Field. Stanford, CA: Stanford Univ. Press

Brint S. 1985. New class and cumulative trend explanations of the liberal political attitudes of professionals. Am. 7. Sociol. 90:30-71

Brint S. 1994. In an Age of Experts. Princeton, NJ: Princeton Univ. Press

Brinton C. 1938 [1965]. The Anatomy of Revolution. New York: Vintage

Bruce-Briggs B, ed. 1979. The New Class? New York: McGraw Hill

Brym R. 1980. Intellectuals and Politics. London: Allen \& Unwin

Burchell G, Gordon C, Miller P, eds. 1991. The Foucault Effect: Studies in Governmentality. Chicago: Univ. Chicago Press

Callon M. 1998. Introduction: the embeddedness of economic markets in economics. In The Laws of the Markets, ed. M Callon, pp. 1-57. Oxford: Blackwell

Callon M. 2005. Disabled persons of all countries, unite! See Latour \& Weibel 2005, pp. 308-13

Callon M. 2007. What does it means to say that economics is performative? See MacKenzie et al. 2007, pp. 311-56

Camic C, Gross NG. 2001. The new sociology of ideas. In The Blackwell Companion to Sociology, ed. JR Blau, pp. 236-49. Malden, MA: Blackwell

Casanova P. 1999 [2004]. The World Republic of Letters. Cambridge, MA: Harvard Univ. Press

Castel R. 1991. From dangerousness to risk. See Burchell et al. 1991, pp. 281-98

Charle C. 1990. Naissance des "Intellectuels," 1880-1900. Paris: Les Éditions de Minuit

Charle C. 2009. Les intellectuels en Europe dans la seconde moitié du XIX ${ }^{\mathrm{e}}$ siècle, essai de comparaison. See Sapiro 2009c, pp. 69-110

Chomsky N. 1969. American Power and the New Mandarins. New York: Pantheon

Collins HM. 1990. Artificial Experts: Social Knowledge and Intelligent Macbines. Cambridge, MA: MIT Press

Collins HM, Evans R. 2002. The third wave of science studies: studies of expertise and experience. Soc. Stud. Sci. 32:235-96

Collins HM, Evans R. 2007. Rethinking Expertise. Chicago: Univ. Chicago Press

Coser L. 1965 [1970]. Men of Ideas: A Sociologist's View. New York: Free Press

Dahrendorf R. 1953 [1969]. The intellectual and society: the social function of the "fool" in the twentieth century. In On Intellectuals: Theoretical Studies, Case Studies, ed. P Rieff, pp. 53-56. Garden City, NY: Doubleday

Debray R. 1979 [1981]. Teachers, Writers, Celebrities: The Intellectuals of Modern France. London: New Left

Dewey J. 1927. The Public and Its Problems. Athens: Ohio Univ. Press

Dezalay Y, Garth B. 2002. The Internationalization of Palace Wars. Chicago: Chicago Univ. Press

Djilas M. 1957. The New Class: An Analysis of the Communist System. New York: Praeger

Donatich J. 2001. The future of the public intellectual: a forum. Nation, Feb. 12, pp. 25-35. http://www.thenation.com/doc/20010212/forum

Dreyfus HL, Dreyfus SE. 2005. Peripheral vision: expertise in real world contexts. Organ. Stud. 26:779-92

Drezner DW. 2008. Blogs, public intellectuals and the academy. FP: Foreign Policy, May 13. http://drezner.foreignpolicy.com/posts/2008/05/13/blogs_public_intellectuals_and_the_academy

Eisenstadt SM. 1972. Intellectuals and tradition. Daedalus 101:1-19

Epstein S. 1995. The construction of lay expertise: AIDS activism and the forging of credibility in the reform of clinical trials. Sci. Technol. Hum. Values 20:408-37

Epstein S. 1996. Impure Science: AIDS, Activism, and the Politics of Knowledge. Berkeley: Univ. Calif. Press

Eyal G. 2000. Anti-politics and the spirit of capitalism: dissidents, monetarists, and the Czech transition to capitalism. Theory Soc. 29:49-92

Eyal G. 2002. Dangerous liaisons: the relations between military intelligence and middle eastern studies in Israel. Theory Soc. 31:653-93

Eyal G. 2003. The Origins of Postcommunist Elites: From the Prague Spring to the Breakup of Czechoslovakia. Minneapolis: Univ. Minn. Press

Eyal G, Hart B, Onculer E, Oren N, Rossi N. 2010. The Autism Matrix: The Social Origins of the Autism Epidemic. Cambridge, UK /Boston: Polity. In press 
Feeley MM, Simon J. 1992. The new penology—notes on the emerging strategy of corrections and its implications. Criminology 30:449-74

Fleck C, Hess A, Stina LE, eds. 2009. Intellectuals and their Publics: Perspectives from the Social Sciences. Aldershot, Hampshire, UK: Ashgate

Foucault M. 1963 [1994]. The Birth of the Clinic. New York: Vintage Books

Foucault M. 1972. The Archaeology of Knowledge. London: Tavistock

Foucault M. 1977-1978 [2007]. Security, Territory, Population: Lectures at the College De France. London: Palgrave Macmillan

Foucault M. 2000. Truth and power. In Essential Works of Michel Foucault, Vol. 3: Power, ed. P Rabinow, JD Faubion, pp. 111-33. New York: New Press

Fourcade M. 2006. The construction of a global profession: the transnationalization of economics. Am. $\mathcal{F}$. Sociol. 112:145-94

Fourcade-Gourinchas M. 2003. What is sociological about the sociology of economics? Some recent developments. Econ. Sociol. Eur. Electron. Newsl. 4(2)

Fuller S. 2004. Intellectuals: an endangered species in the 21st century? Econ. Soc. 33:463-83

Gieryn TF. 1999. Cultural Boundaries of Science: Credibility on the Line. Chicago: Chicago Univ. Press

Gouldner A. 1975-1976. Prologue to a theory of revolutionary intellectuals. Telos 26:3-36

Gouldner A. 1979. The Future of Intellectuals and the Rise of the New Class. New York: Seabury

Gramsci A. 1929-1935 [1971]. Selections from the Prison Notebooks of Antonio Gramsci. New York: Int. Publisher

Gramsci A. 1932 [1995]. Further Selections from the Prison Notebooks. Croce and Fulien. Minneapolis: Univ. Minn. Press

Haas PM. 1992. Introduction: epistemic communities and international policy coordination. Int. Organ. 46:135

Hacking I. 1995. Rewriting the Soul: Multiple Personality and the Sciences of Memory. Princeton, NJ: Princeton Univ. Press

Hamburger J. 1965. Intellectuals in Politics, Fohn Stuart Mill and the Philosophic Radicals. New Haven, CT: Yale Univ. Press

Heilbron J, Sapiro G. 2007. Outline for a sociology of translation: current issues and future prospects. In Constructing a Sociology of Translation, ed. M Wolf, A Fukari, pp. 93-107. Philadelphia, PA: Benjamin N. Am.

Jacobs R, Townsley E. 2010. The Space of Opinion: Media Intellectuals and the Public Sphere. Oxford: Oxford Univ. Press. Under review

Jacoby R. 1987. The Last Intellectuals. New York: Basic Books

Jennings J, Kemp-Welch A, eds. 1997. Intellectuals in Politics: From the Dreyfus Affair to the Rushdie Affair. London: Routledge

Joll J. 1960. Intellectuals in Politics: Three Biographical Essays. London: Weidenfeld and Nicolson

Kauppi N. 1996. French Intellectual Nobility Institutional and Symbolic Transformations in the Post-Sartrian Era. Albany: SUNY Press

Keck M, Sikkink K. 1998. Activists beyond Borders: Advocacy Networks in International Politics. Ithaca, NY: Cornell Univ. Press

Kellner D. 1997. Intellectuals, the new public spheres, and techno-politics. New Polit. Sci. 41-42:169-88

King MR. 2005. Epistemic communities and the diffusion of ideas: central bank reform in the United Kingdom. West Eur. Polit. 28:94-123

Konrad G, Szelényi I. 1979. The Intellectuals on the Road to Class Power. New York: Harcourt Brace Jovanovich

Kurzman C, Owens L. 2002. The sociology of intellectuals. Annu. Rev. Sociol. 28:63-90

Lasch C. 1965. The New Radicalism in America, 1889-1963: The Intellectual as a Social Type. New York: Alfred A. Knopf

Latour B. 1987. Science in Action: How to Follow Scientists and Engineers through Society. Cambridge, MA: Harvard Univ. Press

Latour B. 1999. On recalling ANT. In Actor Network Theory and After, ed. J Law, J Hassard, pp. 15-25. Oxford: Blackwell

Latour B. 2005. From Realpolitik to Dingpolitik. See Latour \& Weibel 2005, pp. 14-41 
Latour B, Weibel P, eds. 2005. Making Things Public: Atmospheres of Democracy. Boston: MIT Press

Lila M. 2001. The Reckless Mind: Intellectuals in Politics. New York: N. Y. Rev. Books

Lippmann W. 1922. Public Opinion. New York: Free Press

Lippmann W. 1927. The Phantom Public. New Brunswick, NJ: Transaction Books

Lipset S, Dobson R. 1972. The intellectual as critic and rebel: with special reference to the United States and the Soviet Union. Daedalus 101:137-98

MacKenzie D, Millo U. 2003. Constructing a market, performing theory: the historical sociology of a financial derivatives exchange. Am. 7. Sociol. 109:107-45

MacKenzie D, Muniesa F, Siu L, eds. 2007. Do Economists Make Markets? On the Performativity of Economics. Princeton, NJ: Princeton Univ. Press

Makhaiski JV. 1899 [1979]. Le Socialisme des Intellectuels. Paris: Editions du Seuil

Mannheim K. 1932 [1993]. The sociology of intellectuals. Theory Cult. Soc. 10:69-80

Mannheim K. 1936. Ideology and Utopia: An Introduction to the Sociology of Knowledge. New York: Harcourt, Brace

Mannheim K. 1956. The problem of the intelligentsia. In Essays on the Sociology of Culture, ed. E Manheim, P Kecskeme, pp. 91-170. London: Routledge \& Kegan Paul

Markoff J, Montecinos V. 1993. The ubiquitous rise of economists. F. Public Policy 13:37-68

Marres N. 2005. Issues spark a public into being: a key but often forgotten point of the Lippmann-Dewey debate. See Latour \& Weibel 2005, pp. 208-17

Martin B, Szelényi I. 1988. Three waves of new class theory. Theory Soc. 17:645-67

Medvetz T. 2009. Les think tanks aux États-Unis. L'émergence d'un sous-espace de production des savoir. Actes Rech. Sci. Soc. 176-77:82-93

Medvetz T. 2010. Think Tanks in America. Oxford: Oxford Univ. Press. In press

Michels R. 1932. Intellectuals. In Encyclopedia of the Social Sciences, ed. ERA Seligman, pp. 118-26. New York: Macmillan

Miller P, Rose N. 1990. Governing economic life. Econ. Soc. 19:1-31

Mills C. 1944 [1963]. The social role of the intellectual. In Power, Politics and People, ed. I Horowitz, pp. $292-$ 304. New York: Ballantine

Mitchell T. 1991. The limits of the state: beyond statist approaches and their critics. Am. Polit. Sci. Rev. 85:77-96

Molnar T. 1961. The Decline of the Intellectual. Cleveland, OH: World Publ.

Montecinos V. 1988. Economics and Power: Chilean Economists in Government, 1958-1985. Pittsburgh, PA: Univ. Pittsburgh Press

Montecinos V, Markoff J. 2001. From the power of economic ideas to the power of economists. In The Other Mirror. Grand Theory through the Lens of Latin America, ed. MA Centeno, F López-Alves, pp. 105-50. Princeton, NJ: Princeton Univ. Press

Nomad M. 1937. Masters—old and new. In The Making of Society, ed. V Calverton, pp. 882-93. New York: Modern Libr.

O'Malley P. 1996. Risk and responsibility. In Foucault and Political Reason, ed. A Barry, T Osborne, N Rose, pp. 189-209. London: UCL Press

Osborne T. 2004. On mediators: intellectuals and the ideas trade in the knowledge society. Econ. Soc. 33:430-47

Posner R. 2001. Public Intellectuals: A Study in Decline. Cambridge, MA: Harvard Univ. Press

Rabeharisoa V, Callon M. 2004. Patients and scientists in French muscular dystrophy research. In States of Knowledge: The Co-Production of Science and Social Order, ed. S Jasanoff, pp. 142-60. London: Routledge

Rahkonen K, Roos JP. 1993. The field of intellectuals: the case of Finland. Int. F. Contemp. Sociol. 30:154-72

Ringer F. 1990. The intellectual field, intellectual history, and the sociology of knowledge. Theory Soc. 19:26994

Ringer F. 1992. Fields of Knowledge: French Academic Culture in Comparative Perspective 1890-1920. Cambridge, UK: Cambridge Univ. Press

Rosch E. 1978. Principles of categorization. In Cognition and Categorization, ed. E Rosch, BB Lloyd, pp. 27-48. Hillside, NJ: Lawrence Erlbaum

Rose N. 1992. Engineering the human soul: analyzing psychological expertise. Sci. Context 5:351-69 
Rose N, O'Malley P, Valverde M. 2006. Governmentality. Annu. Rev. Law Soc. Sci. 2:83-104

Sapiro G. 2003. Forms of politicization in the French literary field. Theory Soc. 32:633-52

Sapiro G. 2009a. Modèles d'intervention politique des intellectuels. Le cas français. Actes Rech. Sci. Soc. 17677:8-31

Sapiro G. 2009b. Introduction. See Sapiro 2009c, pp. 5-26

Sapiro G, ed. 2009c. L'espace intellectuel en Europe-De la formation des Etats-nations à la mondialisation-19ème20ème siècle. Paris: La Découverte

Schumpeter J. 1942. Capitalism, Socialism and Democracy. New York: Harper

Shils E. 1958 [1972]. The Intellectuals and the Powers and Other Essays. Chicago: Univ. Chicago Press

Silverman C, Brosco JP. 2007. Understanding autism: parents and pediatricians in historical perspective. Arch. Pediatr. Adolesc. Med. 161:392-98

Townsley E. 2006. The public intellectual trope in the United States. Am. Sociol. 37:39-66

Tucker A. 2000. The Philosophy and Politics of Czech Dissidence from Patocka to Havel. Pittsburgh, PA: Univ. Pittsburgh Press

Valverde M. 1998. Diseases of the Will: Alcohol and the Dilemmas of Freedom. Cambridge, UK: Cambridge Univ. Press

Walker P. 1979. Between Labor and Capital. Hassocks, UK: Harvester

Werner M, Zimmermann B. 2003. Penser l'histoire croisée: entre empirie et réflexivité. Ann. HSS 1:7-36

White H. 1973. Metahistory: The Historical Imagination in Nineteenth Century Europe. Baltimore, MD: Johns Hopkins Univ. Press

Wynne B. 1996. May the sheep safely graze? A reflexive view of the expert-lay knowledge divide. In Risk, Environment and Modernity, ed. S Lash, B Szerszynski, B Wynne, pp. 44-83. London: Sage

Wynne B. 2005. Reflexing complexity: post-genomic knowledge and reductionist returns in public science. Theory Cult. Soc. 22:67-94

Znaniecki F. 1940 [1968]. The Social Role of the Man of Knowledge. New York: Harper Torchbooks 
$\hat{k}$

\section{Contents}

Annual Review of Sociology

Volume 36, 2010

Frontispiece

fobn W. Meyer xiv

\section{Prefatory Chapter}

World Society, Institutional Theories, and the Actor

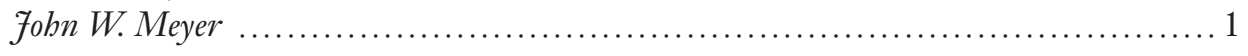

\section{Theory and Methods}

Causal Inference in Sociological Research Markus Gangl .21

Causal Mechanisms in the Social Sciences Peter Hedström and Petri Ylikoski

\section{Social Processes}

A World of Standards but not a Standard World: Toward a Sociology of Standards and Standardization Stefan Timmermans and Steven Epstein

Dynamics of Dyads in Social Networks: Assortative, Relational, and Proximity Mechanisms

Mark T. Rivera, Sara B. Soderstrom, and Brian Uzzi

From the Sociology of Intellectuals to the Sociology of Interventions

Gil Eyal and Larissa Buchbolz

Social Relationships and Health Behavior Across the Life Course

Debra Umberson, Robert Crosnoe, and Corinne Reczek

Partiality of Memberships in Categories and Audiences

Michael T. Hannan ..... 


\section{Institutions and Culture}

What Is Sociological about Music?

William G. Roy and Timothy 7. Dowd

Cultural Holes: Beyond Relationality in Social Networks and Culture

Mark A. Pacbucki and Ronald L. Breiger

\section{Formal Organizations}

Organizational Approaches to Inequality: Inertia, Relative Power, and Environments Kevin Stainback, Donald Tomaskovic-Devey, and Sheryl Skaggs

\section{Political and Economic Sociology}

The Contentiousness of Markets: Politics, Social Movements, and Institutional Change in Markets Brayden G King and Nicholas A. Pearce

Conservative and Right-Wing Movements Katbleen M. Blee and Kimberly A. Creasap 269

The Political Consequences of Social Movements Edwin Amenta, Neal Caren, Elizabeth Chiarello, and Yang Su ... 287

Comparative Analyses of Public Attitudes Toward Immigrants and Immigration Using Multinational Survey Data: A Review of Theories and Research Alin M. Ceobanu and Xavier Escandell 309

\section{Differentiation and Stratification}

Income Inequality: New Trends and Research Directions

Leslie McCall and Cbristine Percheski

Socioeconomic Disparities in Health Behaviors

Fred C. Pampel, Patrick M. Krueger, and fustin T. Denney ...

Gender and Health Inequality

Fen'nan Ghazal Read and Bridget K. Gorman

Incarceration and Stratification

Sara Wakefield and Cbristopher Uggen

Achievement Inequality and the Institutional Structure of Educational

Systems: A Comparative Perspective

Herman G. Van de Werfhorst and fonathan 7.B. Mijs 
Historical Studies of Social Mobility and Stratification

Marco H.D. van Leeuwen and Ineke Maas....

\section{Individual and Society}

Race and Trust

Sandra Susan Smith

Three Faces of Identity

Timothy 7. Owens, Dawn T. Robinson, and Lynn Smith-Lovin

\section{Policy}

The New Homelessness Revisited

Barrett A. Lee, Kimberly A. Tyler, and fames D. Wright

The Decline of Cash Welfare and Implications for Social Policy and Poverty

Sandra K. Danziger

523

Indexes

Cumulative Index of Contributing Authors, Volumes 27-36 _.................. 547

Cumulative Index of Chapter Titles, Volumes 27-36 ............................ 551

\section{Errata}

An online log of corrections to Annual Review of Sociology articles may be found at http://soc.annualreviews.org/errata.shtml 